\title{
Seed Security: Exploring the Potential for Smallholder Production of Certified Seed Crop at Household Level
}

\author{
N. Munyaka ${ }^{1}$, B. M. Mvumi ${ }^{2} \&$ U. M. Mazarura ${ }^{1}$ \\ ${ }^{1}$ University of Zimbabwe, Department of Crop Science, P. O. Box MP 167, Mt Pleasant, Harare, Zimbabwe \\ ${ }^{2}$ University of Zimbabwe, Department of Soil Science \& Agricultural Engineering, P. O. Box MP 167, Mt \\ Pleasant, Harare, Zimbabwe \\ Correspondence: B. M. Mvumi, University of Zimbabwe, Department of Soil Science \& Agricultural \\ Engineering, P. O. Box MP 167, Mt Pleasant, Harare, Zimbabwe. Tel: 263-7-1244-2440; 263-7-7241-9983. \\ E-mail: mvumibm@agric.uz.ac.zw; mvumibm@hotmail.com
}

Received: December 1, 2014 Accepted: December 19, 2014 Online Published: March 30, 2015

doi:10.5539/jsd.v8n2p242 URL: http://dx.doi.org/10.5539/jsd.v8n2p242

\begin{abstract}
Most smallholder farmers in sub-Saharan Africa face food and nutrition security challenges arising from small land size, unavailability of, and poor access to quality seed, inter alia. A survey was conducted in the Zaka district of Masvingo province in Zimbabwe, to investigate the factors that limit smallholder farmers' ability to produce, store or sell certified seed. The factors considered were the availability of certified seed, the appropriateness of storage facilities for seed storage at household level and stored seed pest management. A standard structured questionnaire was administered, between January and May 2013 to 301 farming households. The results showed that the majority of the farmers (66\%) could not procure locally all the seed they required. The only crop which farmers were assured of local availability as certified seed was maize. Farmers reported that the main reasons for the lack of seed for the other crops were: shortage of foundation seed $(39.5 \%)$, lack of knowledge on seed production (34.8\%), seed storage problems $(16.2 \%)$ and small land size $(8.6 \%)$. The majority of the farmers had their stored seed affected by pests with insects accounting for $82.7 \%$ of the damage and loss. The storage facilities used by farmers were not appropriate for effective pest control. Farmers used bedrooms (57\%), granaries (19\%), metal drums (11.5\%), kitchens $(10.4 \%)$ and other places $(2.5 \%)$ to store seed. Some of the facilities such as bedrooms create pest management challenges. The significant correlation between some seed storage factors indicate these factors should be monitored concurrently when dealing with smallholder farmers as they affect each other. Any seed intervention aimed at increasing availability of quality seed to farmers needs a holistic lens which considers the whole seed value chain from production, storage, pest management up to marketing, for it to have any meaningful impact. Not all other crop seeds were available, with sugar bean seed having the highest shortage. There is potential for business development if the seed crops in short supply are produced locally, especially after further verification of effective demand. Research institutions should explore mechanisms of increasing the uptake of their newer varieties by smallholder farmers through increased early interactions with the farmers. Smallholder farmers can be contracted by seed-houses to produce certified seed or to establish community seed enterprises that supply certified seed in their local communities. This would require adequate capacity building and availing desired foundation seed.
\end{abstract}

Keywords: seed security, seed quality, seed availability and accessibility, smallholder farmers, community seed enterprise

\section{Introduction}

Accessibility and availability of seed affect the ability of farmers to produce crops. The availability of quality seed is the basis for food production and improved yields and a source of crop and food variety (Setimela et al., 2004). FAO (2012), provided guidelines recommending that, in humanitarian agricultural assistance programmes, only certified seed should be included in electronic voucher (e-voucher) programmes (Note 1). By pushing for quality standards, the Food and Agriculture Organisation (FAO) realised the need for quality seed to be supplied to farmers. Smallholder farmers in Zimbabwe face a number of challenges that discourage them from growing certain crops because of the unavailability of desired seed. Quality seed of any preferred varieties is the basis of improved agricultural productivity (Pelmer, 2005). Sperling \& Cooper (2003) defined seed security as when a 
household can access sufficient quantities of seed of their preferred variety, possessing the right physical qualities and physiological characteristics, and must be available at the right time. The unavailability of the seed desired by farmers affects the quality of their crop. Sometimes the seed available will have been recycled many times resulting in loss of genetic potential due to continued segregation and gene loss. This loss in genetic potential in turn reduces crop yield potential. There is a slow rate of movement of improved genetic material into smallholder farming communities (Monyo et al., 2004), which reduces attainable yields. Most smallholder farmers are located in marginal areas where crops bred and developed for relatively higher potential parts of the country may not perform well as the farmers do not receive rainfall reliable enough to support the seed type supplied to them. This means the varieties they grow are not optimised for their local conditions. The fact that farmers can afford neither to irrigate their lands nor to use agrochemicals, exacerbates the situation. Seed security is linked to food security in that quality germplasm is a prerequisite for increased yields (Bellon et al., 2003). The varieties of seed used should match the environmental conditions of an area in order for it to be of value to farmers. The present study sought to analyse the challenges that the smallholder farmers face which reduce their ability to use superior germplasm of crops which they produce for home use or for the market. Understanding the challenges farmers face in accessing seed helps in designing and implementing programmes that respond to seed security issues and hence food and nutrition security. Thus the main objectives of the study were to characterise smallholder seed systems and identify bottle-necks in the postharvest handling of seed.

\section{Materials and Methods}

\subsection{Site Description}

A survey was conducted between January and May 2013, focusing on unravelling the various seed challenges faced by smallholder farmers in Zaka district of Masvingo province in Zimbabwe (Fig. 1).

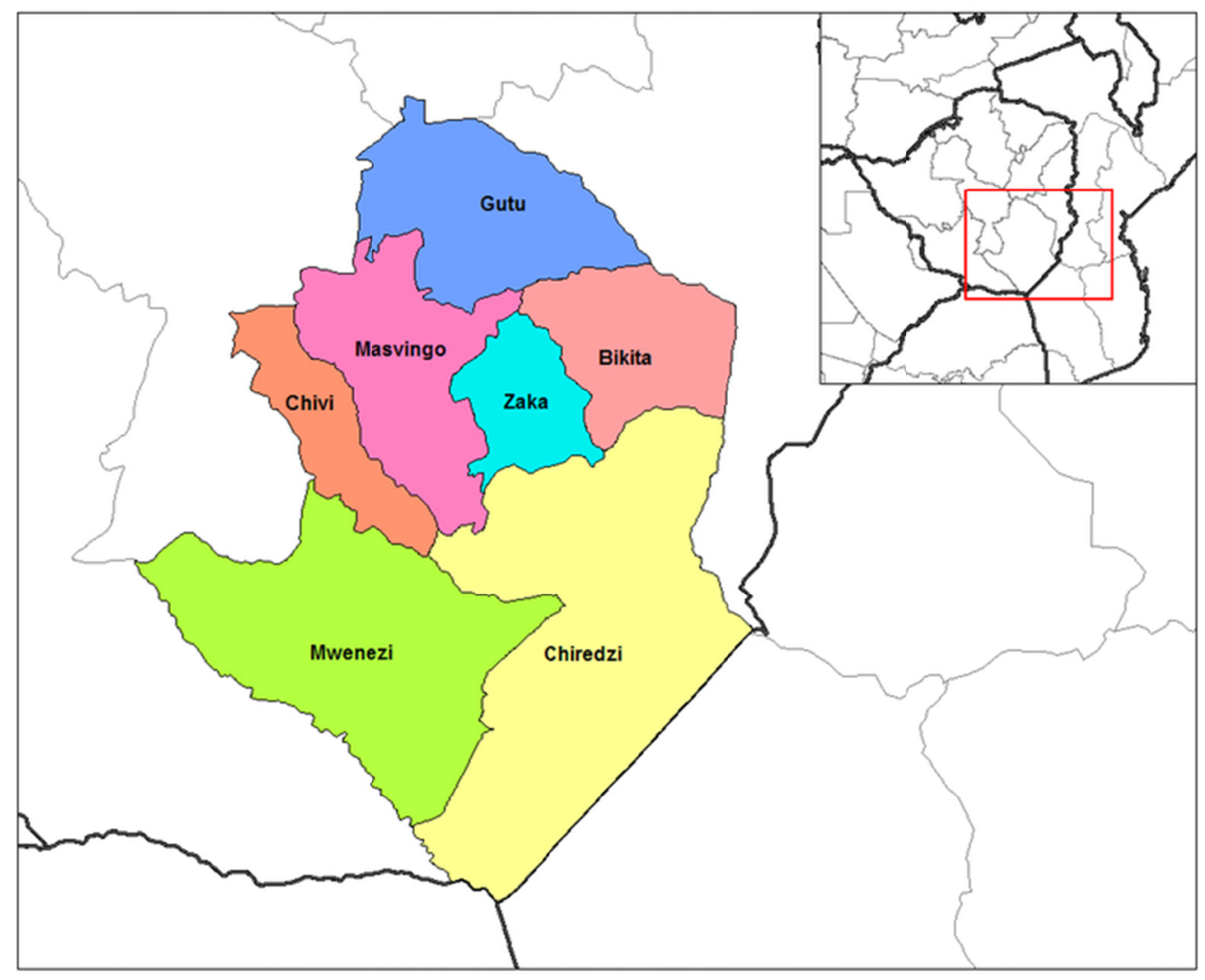

Figure 1. The location of Zaka district, in Masvingo province, Zimbabwe, where the survey challenges faced by smallholder farmers in accessing seed was conducted

Zaka district is a typical semi-arid area dominated by natural regions IV and V (Table 1). The district receives an annual precipitation ranging from 450 to $650 \mathrm{~mm}$ (FAO, 2014). 
Table 1. Typical agro-ecological characteristics of Zaka district

\begin{tabular}{|c|c|c|c|}
\hline $\begin{array}{l}\text { Natural } \\
\text { region* }\end{array}$ & $\begin{array}{l}\% \\
\text { Area }\end{array}$ & $\begin{array}{l}\text { Annual } \\
\text { rainfall (mm) }\end{array}$ & Remarks \\
\hline III & 18 & $500-750$ & Relatively high temperature; subject to severe mid-season drought \\
\hline IV & 30 & $450-650$ & $\begin{array}{l}\text { Severe dry spells during the rainy season, and frequent seasonal } \\
\text { droughts; normally considered unsuitable for dryland crop production }\end{array}$ \\
\hline $\mathrm{V}$ & 52 & $<450$ & $\begin{array}{l}\text { Highly erratic rainfall; poor soils normally considered unsuitable for } \\
\text { crop production }\end{array}$ \\
\hline
\end{tabular}

*Natural regions are agro-ecological zones classified mainly on the basis of rainfall amount and temporal distribution. There are six main zones and the others are I $(\geq 1000 \mathrm{~mm}$; most of which falls throughout the year; good soils), IIa (750-1000 mm; good temporal distribution; generally good soils), IIb (same as IIa but less reliable) [Adapted from : Department of the Surveyor General, 1984]

\subsection{Data Collection Tools, Respondents and Enumerators}

Data were collected using a standard structured questionnaire composed of: general information of respondent; types of crops normally grown by the respondent; seed production experience, postharvest management and marketing of the seed. The questionnaire was administered to 330 farming households in 15 out of 34 wards of Zaka district and full responses were obtained from 301 households. The other 29 questionnaires were not returned as farmers lost or misplaced them which made it difficult for the enumerators to retrieve them. The enumerators were agricultural extension officers resident in the target wards. Prior to the survey, the extension staff were trained on the correct interpretation of questions in the survey questionnaire for them to solicit accurate responses from farmers in their wards. The extension officers delivered questionnaires to randomly chosen farmers who answered the questions independently with assistance of extension staff only when necessary. The first 10 wards were where the Seeds and Market project (SAMP) implemented by GRM International (GRM), had trained farmers in seed production and had also assisted the farmers to produce certified seed. A total of 200 seed producers from these wards responded to the questionnaire. The trained farmers formed a seed growers association for the district which later evolved into a community seed company. The farmers' knowledge and two years' experience in seed production was expected to give them clear insights on what was expected in seed production in a smallholder setting. The other five wards were randomly chosen from a list of 10 provided by the Department Agricultural Technical and Extension Services (Agritex) office of Zaka district. A total of 101 farming households from the five wards responded to the questionnaire.

\subsection{Sampling}

Zaka district is composed of farmers engaged in certified seed production and some who are not. In the wards where SAMP has been implemented, the list of all farmers involved was used as the sample frame to provide respondents. A different sampling strategy had to be used to select non-seed producers because there were no household lists as in the case of seed growing wards. Where no seed producers' lists were available, each ward was divided by the number of villages. On average the wards had 3 to 4 villages in Zaka. Each ward had an allocation of 20 questionnaires and each village received a proportional number of questionnaires. At the village level, the enumerator started with the second homestead and subsequently, a single homestead was picked after every three other homesteads until the required numbers of households were obtained.

\subsection{Data Analysis}

Data from the questionnaires were entered into the Statistical Package for Social Sciences (SPPSS) version 22.The data were analysed for frequency and correlations.

\section{Results}

\subsection{Demographics}

The respondents were almost equal in sex representation with females being slightly more than the males (Table.2) 
Table 2. The sex distribution of farmers involved in the survey, Zaka district, Zimbabwe (January to May 2013)

\begin{tabular}{lll}
\hline Sex & Frequency & Percent \\
\hline Female & 155 & 51.5 \\
Male & 145 & 48.2 \\
Not indicated & 1 & 0.3 \\
Total & 301 & 100.0 \\
\hline
\end{tabular}

The main occupation of respondents in Zaka district was farming (Table.3). The fact that the majority of respondents were farmers indicated the relevance of the target group and that their perception on seed issues were relevant as they were directly involved in seed issues for their livelihoods.

Table 3. The main occupation of the household heads interviewed in the survey, Zaka district, Zimbabwe (January to May 2013)

\begin{tabular}{lll}
\hline Occupation & Frequency & Percent \\
\hline Bishop & 2 & 0.7 \\
Farmer & 281 & 93.4 \\
Builder & 4 & 1.3 \\
Businessman & 2 & 0.7 \\
Businesswoman & 1 & 0.3 \\
Councillor & 2 & 0.7 \\
Extension worker & 1 & 0.3 \\
Housewife & 1 & 0.3 \\
Pastor & 1 & 0.3 \\
Pensioner & 1 & 0.3 \\
Poultry farmer & 1 & 0.3 \\
Teacher & 3 & 1.0 \\
Youth officer & 1 & 0.3 \\
Total & 301 & 100 \\
\hline
\end{tabular}

\subsection{Seed Access and Availability}

The majority of farmers did not have enough seed for all crops (Table 4).

Table 4. Availability and access to certified seed by farmers interviewed in the survey, Zaka district, Zimbabwe (January to May 2013)

\begin{tabular}{lrr}
\hline Response to seed access by farmers & Frequency & Percent \\
\hline Yes & 101 & 33.6 \\
No & 197 & 65.5 \\
Not answered & 3 & 1.0 \\
Total & 301 & 100 \\
\hline
\end{tabular}

The unavailability of foundation seed (39.5\%) and lack of knowledge on seed quality (34.8\%) were the main factors farmers cited as reasons for not producing enough seed (Fig.2). Storage problems (16.2 \%) and land size $(8.6 \%)$ were also mentioned as factors affecting farmers in Zaka district. 


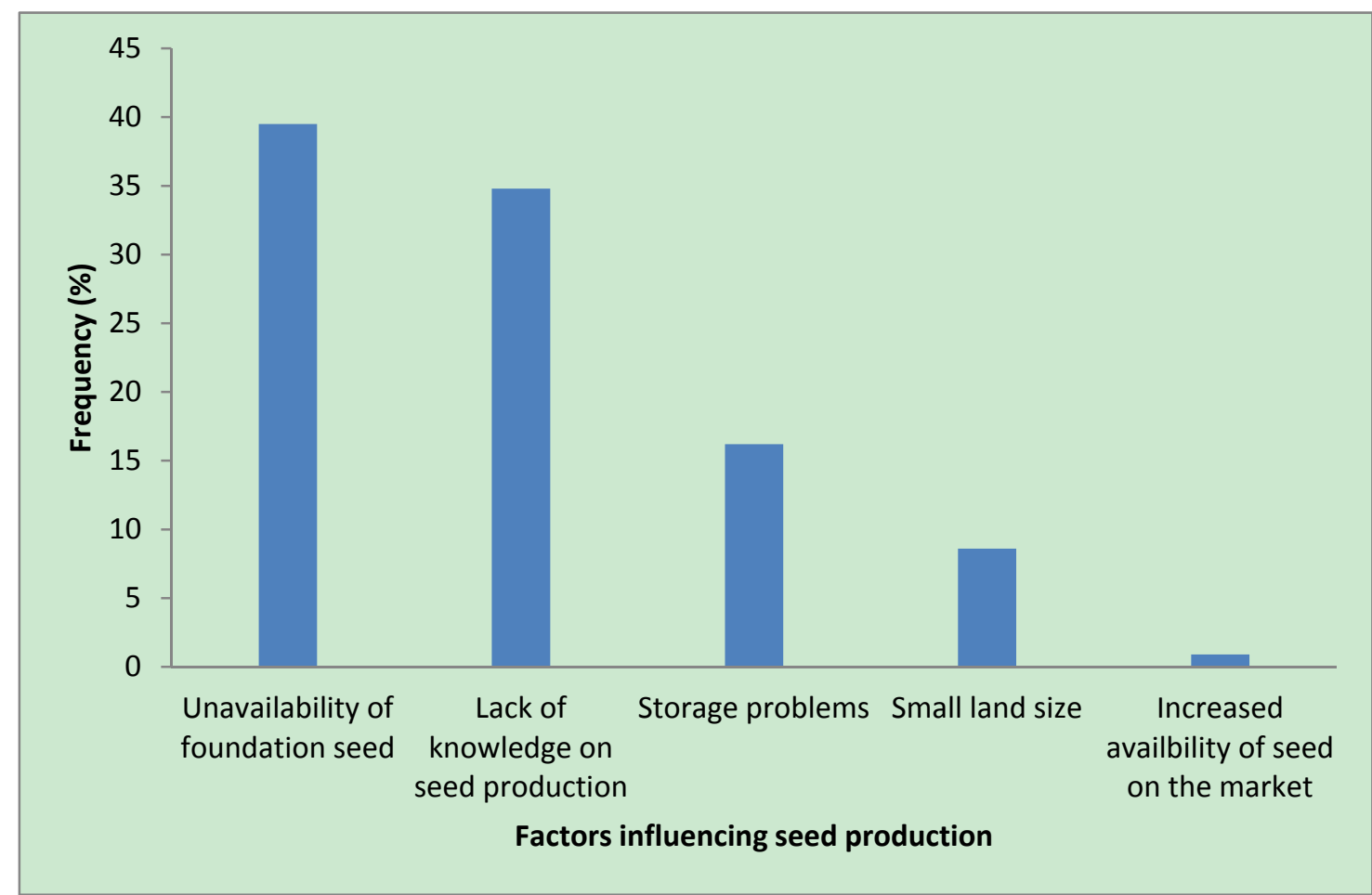

Figure 2. Factors influencing farmers' ability to produce certified in Zaka, Zimbabwe, according to survey done from January to May 2013

About $56 \%$ of the farmers accessed new seed varieties through informal channels with non-governmental organisations (NGOs) being the major player servicing almost $50 \%$ of the respondents (Table 5). The seed companies were mentioned by $27 \%$ of the farmers.

Table 5. The agents of new variety introduction to farmers and their \% contribution, as revealed in the survey, Zaka district, Zimbabwe (January to May 2013)

\begin{tabular}{lll}
\hline Agent & Frequency & Percent \\
\hline Department of Research and Specialist Services & 24 & 16.7 \\
NGOs & 68 & 47.2 \\
Seed company & 39 & 27.1 \\
Other farmers & 13 & 9.0 \\
Total & 144 & 100.0 \\
\hline
\end{tabular}

The respondents showed that $68 \%$ of the interviewees had land less than 2 hectares (Table 6 ).

Table 6. The land size distribution in hectares owned by the farmers as revealed in the survey, Zaka district, Zimbabwe (January to May 2013)

\begin{tabular}{lll}
\hline Land size & Number of respondents & Percent of farmers \\
\hline Less than 0.8 ha & 20 & 6.4 \\
Between 0.8-1.6ha & 91 & 30.3 \\
From 1.7-2 ha & 94 & 31.3 \\
More than 2 ha & 96 & 32.0 \\
\hline
\end{tabular}




\subsection{Seed Purchasing Pattern}

The majority of farmers $(89.5 \%)$ had access to certified seed. The results indicated a high usage and hence indirectly, potential availability of certified seed. The data were further analysed to identify crops for which certified seed was purchased. Maize (Zea mays L.) seed was the most available seed, accounting for $77.2 \%$ of all seed farmers accessed (Table.7). It was also the main seed they bought as certified seed. Some small amount of cowpea (Vigna unguiculata, L.) was available (13.6 \%) and Bambara nuts (Vigna subterranean L.) were totally not available as certified seed to any of the respondents (Table.7).

Table 7. The various seed types purchased as certified seed as revealed in the survey, Zaka district, Zimbabwe (January to May 2013)

\begin{tabular}{ll}
\hline Crop type & Percentage of seed purchased \\
\hline Maize (Zea mays) & 77.2 \\
Cowpeas (Vigna unguiculata) & 13.6 \\
Sugar beans (Phaseolus vulgaris) & 3.2 \\
Sorghum (Sorghum bicolour) & 3.2 \\
Groundnuts (Arachis hypogaea) & 1.6 \\
Rice (Oryza sativa) & 1.2 \\
Bambara nuts (Vigna subterranea) & 0.0 \\
Total & $\mathbf{1 0 0 . 0}$ \\
\hline
\end{tabular}

Farmers could not access some desired seed as certified seed and therefore considered such seed to be in short supply (Fig.3)

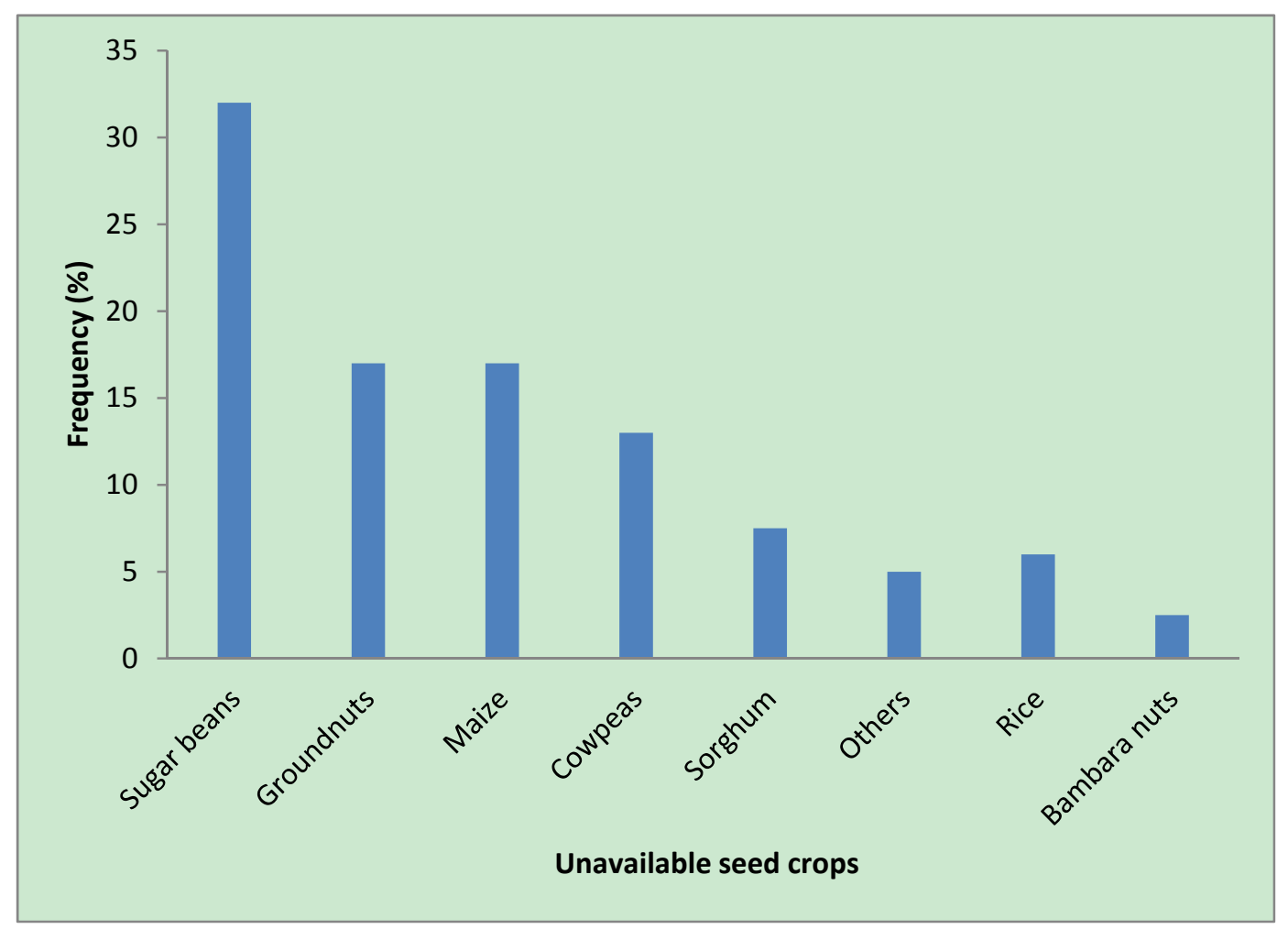

Figure 3. Seed crops which farmers could not access in their areas, interviewed in the survey, Zaka district, Zimbabwe (January to May 2013) 
Crops are considered important by farmers in terms of production levels and utility derived from them (Table 8). The majority of farmers indicated that maize was the most important crop as it ranked the first in $73 \%$ of the cases. Groundnuts were considered the second most important by the interviewees.

Table 8. The farmer ranking according to importance of crops for the household consumption, interviewed in the survey, Zaka district, Zimbabwe (January to May 2013)

\begin{tabular}{llllll}
\hline Crop Type & First (\%) & Second (\%) & Third (\%) & Fourth (\%) & Fifth (\%) \\
\hline Maize & 84.2 & 3.1 & 4.2 & 5.4 & 3.1 \\
Cowpeas & 21.8 & 6.0 & 15.7 & 29.4 & 26.6 \\
Groundnuts & 3.5 & 64.2 & 26.0 & 4.2 & 2.1 \\
Bambara nut & 0.0 & 6.7 & 36.6 & 36.2 & 20.5 \\
Finger millet & 1.7 & 26.7 & 40.0 & 14.2 & 15.8 \\
Sorghum & 4.3 & 22.1 & 20.0 & 27.9 & 25.7 \\
Rice & 0 & 0 & 0 & 0 & 0 \\
Sugar beans & 4.4 & 15.6 & 15.6 & 53.3 & 8.9 \\
\hline
\end{tabular}

With regard to where seed was stored, the majority of farmers (57\%) used the bedroom as a storage place, followed by $18.9 \%$ who used the granary (Fig. 4). Some of the seed storage facilities indicated by farmers were unsuitable for maintaining seed quality, for example $10.4 \%$ of the farmers bagged their seed and kept it in the kitchen.

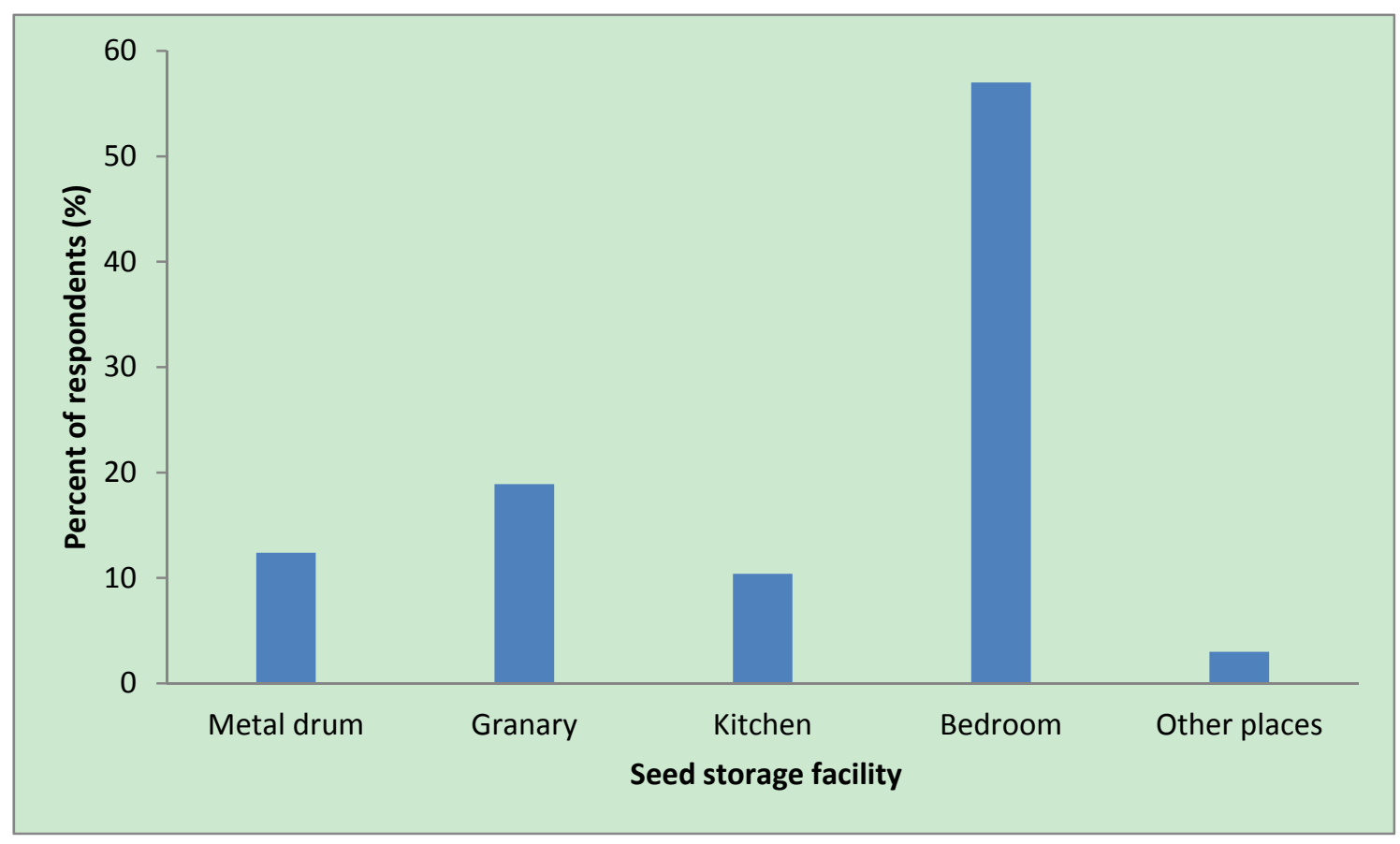

Figure 4. The various seed storage facilities used by farmers, interviewed in the survey, Zaka district, Zimbabwe (January to May 2013)

With regard to seed pest challenge, the majority of the respondents noted pest damage as their main problem (Table. 9). The other factors such as moisture in grain and theft of seed in storage were regarded as insignificant. 
Table 9. Seed storage problems faced by farmers interviewed in the survey, Zaka district, Zimbabwe (January to May 2013)

\begin{tabular}{lll}
\hline Problem Faced & Frequency & Percent \\
\hline Pest damage & 114 & 85.7 \\
Small space available & 8 & 6.0 \\
Lack of durable material & 4 & 3.0 \\
High moisture affecting seed & 1 & 0.8 \\
Theft & 6 & 4.5 \\
Total & 133 & 100 \\
\hline
\end{tabular}

Insect pests (common weevils and the larger grain borer) accounted for $82.7 \%$ of damage and loss to stored seed while fungal rots and rat damage had minimal effect on stored seed (Fig. 5).

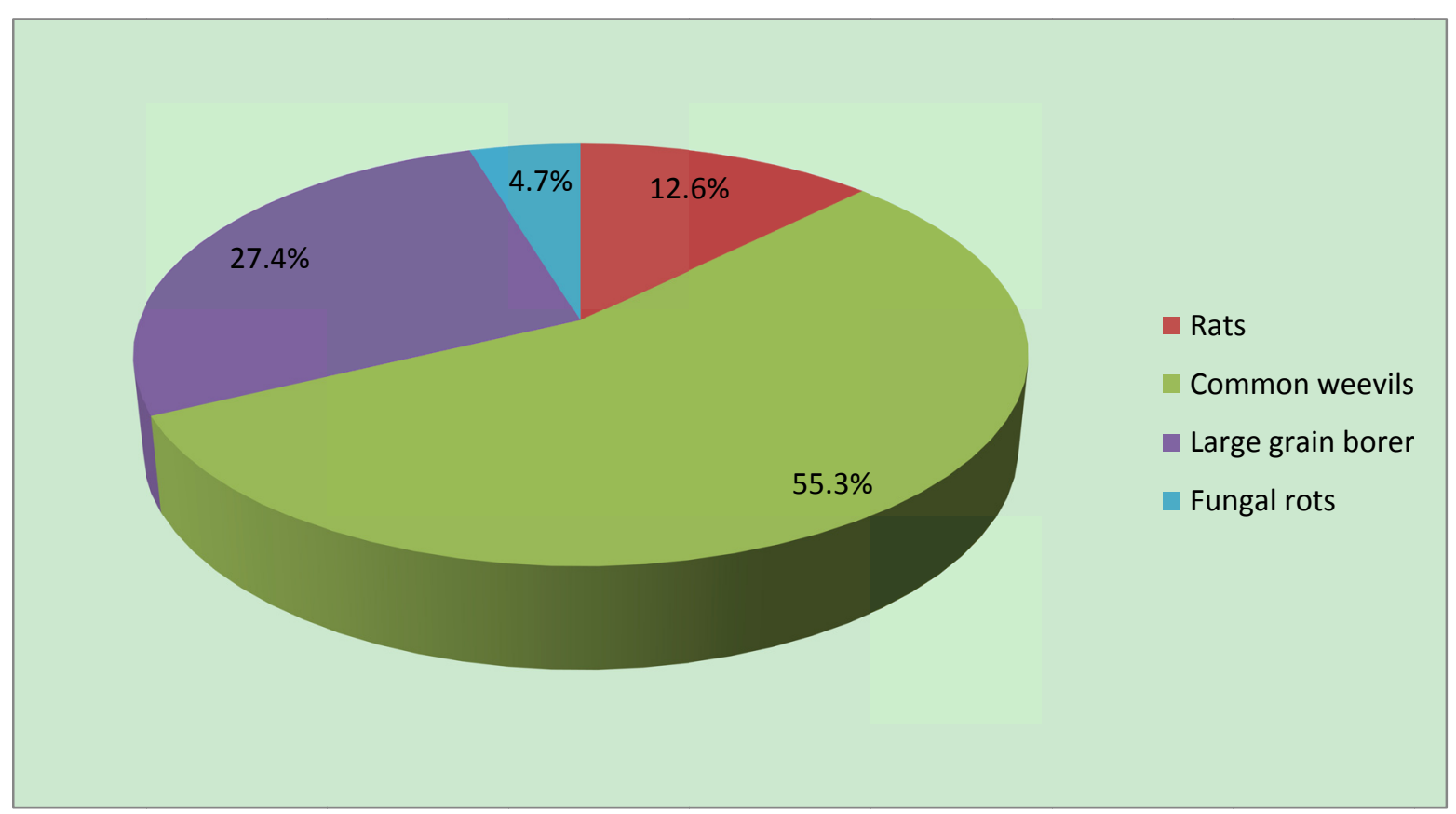

Figure 5 . The percentage of seed damage caused by various pests as revealed by farmers interviewed in the survey, Zaka district, Zimbabwe (January to May 2013)

\subsection{Seed Loss in Storage}

A total of $67 \%$ of the farmers experienced seed loss in storage. The loss of own stored seed was mainly due to attack by insect pests. Most of the farmers $(79.3 \%)$ used chemical control methods to keep their seed free from pests while a considerable proportion $(15.9 \%)$ used traditional methods. The traditional methods involved the use of plant leaves such as those of gumtrees (Eucalyptus spp.) and mexican marigold (Tagetes minuta L.) infused into the grain to prevent insect infestation. The other traditional method used was storing the seed in sealed gourds. A low percentage of farmers $(4.8 \%)$ had knowledge of new structures as a solution to pest problems. 


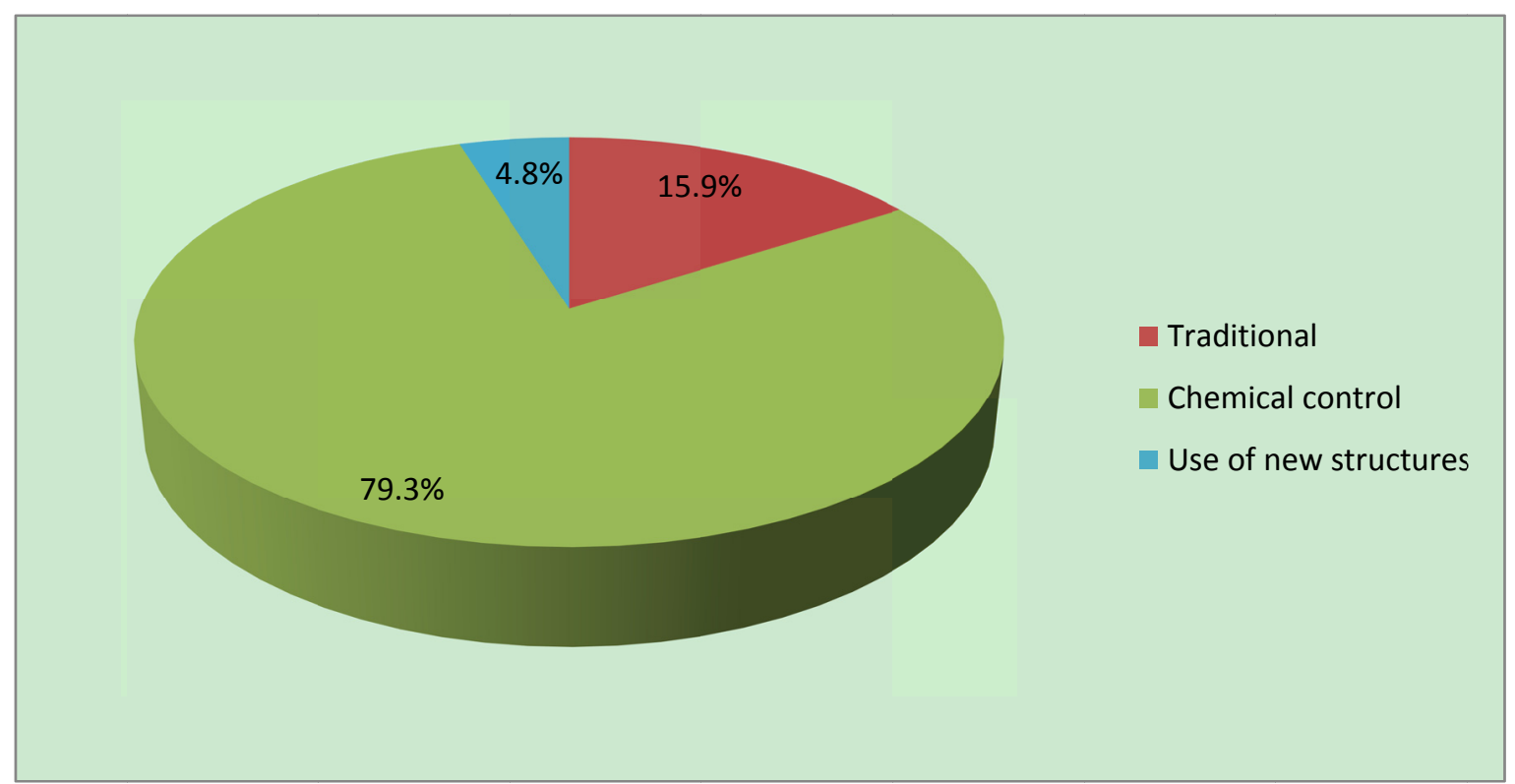

Figure 6. The different control methods of storage insect pests used by farmers interviewed in the survey, Zaka district, Zimbabwe (January to May 2013)

While a high percentage of farmers used mainly the chemical synthetic pesticide Shumba Super dust (fenitrothion $1 \%$ and deltamethrin $0.13 \%$ ) to protect their seed, farmers still experienced losses of the stored seed due storage insect pest attack.

\subsection{The Relationships between the Factors in the Survey}

The factors limiting seed production in Zaka district showed that some were positively correlated while others were negatively correlated (Table 10). There was a positive correlation between the presence of a market and increased seed production by farmers and between training in seed production and interest in seed production. Factors such as sex of household head did not affect the availability of enough seed. Availability of seed and crops of interest to the farmers were negatively correlated. The other factors analysed in survey showed no correlation.

Table 10. The correlation of various factors limiting seed accessibility to farmers interviewed in the survey, Zaka district, Zimbabwe (January to May 2013)

\begin{tabular}{|c|c|c|c|c|}
\hline Variable & $\begin{array}{l}\text { Sample } \\
\text { size }\end{array}$ & $\begin{array}{l}\text { Pearson's } \\
\text { coefficient }\end{array}$ & Correlation & P-Values \\
\hline $\begin{array}{l}\text { a) Was enough seed grown vs Market for the seed } \\
\text { sold }\end{array}$ & 298 & & 0.288 & $0.00 \mathrm{~A}$ \\
\hline b) Was enough seed grown vs land size & 298 & & 0.034 & 0.565 \\
\hline $\begin{array}{l}\text { c) Was enough seed grown vs Number of years as a } \\
\text { farmer }\end{array}$ & 298 & & -0.166 & $0.004 \mathrm{~A}$ \\
\hline d) Was enough seed grown vs Source of seed & 298 & & -0.029 & 0.614 \\
\hline e) Farmer type vs Was enough seed grown & 301 & & 0.21 & $0.00 \mathrm{~A}$ \\
\hline f) Sex of household head vs Enough seed & 298 & & -0.041 & 0.486 \\
\hline g) Sex of household head vs Land size & 297 & & -0.145 & $0.013 \mathrm{~A}$ \\
\hline $\begin{array}{l}\text { h) Longest time seed has been retained vs Types of } \\
\text { crops grown }\end{array}$ & 240 & & -0.118 & $0.067 \mathrm{~A}$ \\
\hline I) Growing of $\mathrm{s}$ seed crop vs Training on seed & 248 & & 0.48 & $0.00 \mathrm{~A}$ \\
\hline
\end{tabular}


production

j) Price perception vs Availability of seed

J) Training on seed production vs Interest in training by farmers

k) Availability of seed vs Crops of interest

1) Storage problems faced vs Main pests in storage

m) Main pest in storage vs Control method for pest

n) Most preferred method vs Storage place for seed

$\begin{array}{lrr}141 & 0.233 & 0.005 \mathrm{~A} \\ 150 & -0.319 & 0.00 \mathrm{~A} \\ & & \\ 179 & -0.161 & 0.032 \mathrm{~A} \\ 132 & 0.113 & 0.196 \mathrm{~A} \\ 213 & -0.048 & 0.489 \\ 247 & 0.145 & 0.023 \mathrm{~A}\end{array}$

A indicates a significant relationship at $p$ level of 0.05

\section{Discussion}

The high number of respondents (93\%) who said their main occupation was farming showed the importance of farming to the general populace in the district. The land holding in Zaka district was small per farmer with $68 \%$ of respondents having an average land area of less than 2 hectares. This indicated that most farmers did not have enough land to afford isolation distances and good rotations during seed production as required by the Seed Services Unit, the national seed regulatory authority, in the Department of Research and Specialist Services. The shortage of land in the smallholder farming sector has been cited as one of the causes of reduced seed production (CIAT et al, 2009).. However, land size was not considered by respondent farmers a strong factor influencing seed availability due to the potential alternative of using all available land for seed production and the proceeds from the seed used to purchase grain for food.

About $76 \%$ of seed bought by farmers was certified maize seed. According to Langyintuo et al. (2010), $68 \%$ of all seed sold by seed maize companies in Zimbabwe is certified maize seed. Thus farmers are more likely to get maize as certified seed than any other seed. This finding concurs with Rohrbach and Mazvimavi (2006) who reported that $81 \%$ of seed purchased by farmers at seed fairs was maize seed. The seed security assessment report for Zimbabwe put the figure for informal seed supply at $95 \%$ for all other crops except maize (CIAT et al, 2009), clearly showing that very little of other crops are supplied by formal seed companies. When seed is supplied informally, no quality can be assured unlike in the formal market.

The remaining percentage of certified seed was mostly composed of cowpeas. The lack of certified seed of most crops is because seed companies are profit-driven and hence concentrate on hybrid seed maize and vegetables seed targeted for high value markets (Zerbe, 2001; Jones et al., 2001; Daniel \& Adetumbi, 2004). The thrust of private companies suggest that an alternative mechanism has to be developed to meet the farmers' needs with seeds considered of less commercial interest but desired by farmers.

Of significant note is the fact that not a single farmer indicated having access to certified seed of bambara nuts (Jugo beans). The result possibly indicates that there are crops farmers desire to grow but cannot access the improved germplasm. Farmers in Zaka district tend to use retained seed (Mvumi et al, 2010). Farmers in Tanzania recycled bean seed six times before purchasing new seed (Rubyogo et al, 2007). This suggests that one of the reasons why farmers are not getting good yields of most crops is the absence of quality seed and the use of recycled seed. The private seed industry has not found the bean seed business lucrative, as once farmers get new germplasm they tend to re-cycle from their own harvests for many seasons, instead of purchasing fresh seed from certified sources (David \& Sperling, 1999).The commercial seed businesses do not put resources into crops that have low profit margins and can be used as recycled seed after initial purchase.

\subsection{Sources of New Seed Varieties for Farmers}

Farmers accessed germplasm of new varieties mainly from NGOs and other farmers which is not ideal. This is because the two sources mentioned in the survey are informal and may not have the best technical ability to support the varieties they introduce. Most countries in the Southern African Development Community (SADC) region have less than $10 \%$ of their area planted to improved sorghum or millet varieties (Monyo \& Mgonja, 2004), which was confirmed in the current studies. The results also confirmed findings by Setimela et al. (2003), who reported lack of knowledge and shortage of foundation seed as the main reasons for reduced seed supply to smallholder farmers. The challenges faced by farmers emanates from problems in distribution and seed multiplication of improved varieties. There has been considerable breeding research, but the rate of adoption of improved crop varieties by farmers in sub-Saharan Africa remains less than $5 \%$ (Monyo and Mgonja, 2004). 
The low rate of adoption can be attributed to the unavailability of foundation seed of the improved seed and lack of promoters for the new varieties. Training farmers on seed quality standards coupled with timely provision of foundation seed at the correct prices would greatly reduce seed shortage to farmers. The results from the current study reflect the fact that, while maize seed is available as certified seed, other crops like groundnuts, rice, and sugar beans are not easily accessible by farmers as certified seed. The slow filtering of improved seed varieties is a result of the absence of a clear policy of cascading the varieties to farmers from research organisations. The fact that NGOs distribute new varieties to farmers means the varieties would only be available when some company has bulked or multiplied the particular variety or varieties in response to the NGO tenders but not as a deliberate commercial strategy to have farmers access the improved germplasm. This practice is not sustainable as this is a humanitarian rather than a technical or market-driven intervention.

\subsection{Distribution Mechanisms of Seed for Varieties}

Drought relief programmes in southern Africa have provided a way for farmers to access new varieties of seed of basic food crops. However, this remains an inefficient process (Rohrbach \& Mazvimavi, 2006). The work of relief organisations across Zimbabwe has made them a major source of new varieties in the past 10 years. Thus NGOs introduce new varieties instead of the researchers and seed companies. Strategies or policies have to be developed which link seed breeding research systems with farmers' representatives to cascade new varieties which commercial seed companies may not necessarily be interested in multiplying and marketing. This will increase the benefits to farmers despite the non-involvement of seed companies.

The inadequate involvement of the beneficiaries in the choice of type of seed distributed by NGOs often results in poor choices of crops for the farmers (Langyintuo \& Setimela, 2009). The involvement of local communities in seed issues that concern them would result in increased product utility as indigenous knowledge systems (IKS) are infused with scientific research. The IKS techniques that farmers use in maintaining the seed quality and protection of seed have potential to be integrated with modern methods. There are many IKS which are not tested but could be used in conjunction with modern chemical methods to improve efficacy. Technologies and practices for small grain producers were confirmed as effective in grain protection (TECA/FAO, 2012). Parwada et al. (2012) confirmed the effect of T. minuta on Sitophilus spp. The gourds used by farmers in storing seed, prevent pests from entering if tightly closed, and those pests inside would not survive due to lack of oxygen. For example seed maize cobs were preserved by "smoking" them on a line running above and across the kitchen heath. The effect of this practice on seed viability and vigour is not scientifically known.

There is need for a policy change or development of new strategies pertaining to the distribution of foundation seed and training of farmers on seed systems for the unavailable seed crops. New extension strategies and methods of information dissemination have to be developed by seed houses and government departments to reach more farmers especially with regard to new varieties. Smallholder farmers seem to get low yields partly because of the low genetic potential of the crops they grow since they face serious challenges in accessing new germplasm.

The fact that $65.5 \%$ of the farmers did not have enough seed for their requirements meant productivity was compromised as low quality retained seed was used. By deduction, this could mean that the $66.1 \%$ who faced seed shortages had to resort to the use of retained grain as seed.

\subsection{Potential Business Development on Unavailable Seed}

There is a potential market niche for quality seed supply to smallholder farmers for groundnuts, rice, bambara nuts, sorghum and sugar beans. Other researchers reported that the percentage of farmers in southern Africa using informal seed channels account for more than $90 \%$ (Monyo et al., 2004; CIAT et al, 2009) of all farmers. The high number of farmers using informal seed channels means farmers lack access to improved varieties and continue to recycle seed that is exhausted after generations of cultivation. The farmers end-up using retained seed due to the high cost of certified seed. The seed sold in informal channels lacks authentication and there is no means of restitution for buyers in the event of poor performance. The recycling has resulted in poor yields and hence food insecurity. The production of legumes for food and seed in smallholder farming areas has not increased and yet they are very important in improving the nutrition of poor households who need a source of protein. The legumes are also important for improving soil nutrition and productivity through biological nitrogen fixation (Svubure et al., 2010).

\subsection{Seed Postharvest Storage Facilities and Pest Management}

Seed maybe produced but in the absence of proper storage management, farmers lose seed to theft, insect and rodent damage and fungal rots. The damage to the seed implies loss of germination capacity and actual weight as 
the weevils and other pests feed on the seed. The rots are usually prevalent whenever seed of unsuitably high moisture is stored for later use. The variety and quality of storage places used by farmers such as bedrooms and kitchen frequently show that this is a key area that must be addressed by the farmers. The type of storage facilities for seed may cause damage through temperature fluctuations and insect and/or rodent attack as the facilities were not suitable. The bedroom, for example, limits the type of chemical control methods farmers can use as the farmer sleeps in that room every day. The chemical used did not effectively control the storage insect pests attacking the seed. This may be related to the chemicals used or the storage place used. The indications were that the majority of farmers had structures that were inappropriate for effective pest control, especially fumigation.

The absence of proper storage facilities resulted in the farmers losing seed in many ways such as loss of vigour or insect pest and disease damage. The kitchen, for example, was often used for seed storage yet it experiences high temperatures. The high temperatures may affect the seed viability. Farmers cited damage by insect pests as a major problem during seed storage. The mention of the larger grain borer (LGB), Prostephanus truncatus Horn. by farmers was followed up with agricultural extension staff in the area, who denied the presence of the pest. According to the response by farmers, $27.4 \%$ of the seed damage was caused by LGB. Followup investigations confirmed that there could be issues of insect pest mis-identifcation as farmers were unable to identify the LGB. Further discussions with the district extension staff revealed that no proper crop postharvest management training had been provided to the district staff and therefore there could also be a knowledge gap on the part of extension staff; particularly with regards to correct identification and recognition of the LGB. The pest is known to have spread to most parts of Zimbabwe (Nyagwaya et al., 2010).

The effect of diseases, moisture and lack of durable material for seed storage are insignificant in the view of the farmers. This can be attributed to climatic conditions. Zaka district has an annual rainfall range of 450 to 650 $\mathrm{mm}$ and temperature range of $15{ }^{\circ} \mathrm{C}$ to $40{ }^{\circ} \mathrm{C}$ (Anon., 2014; FAO, 2014). The high ambient temperature and low rainfall reduce the impact of diseases such as fungal rots. From these results, pest management needs greater emphasis especially on effective seed protectants and appropriate facilities for seed storage. There are over 60 insect species which infest stored grain (Herbert, 2012) and there is a high risk of seed damage and subsequent loss to attack by some of these pests.

Any program, which seeks to increase seed security, will need to seriously consider postharvest pest management as a key component of the intervention. Some of the storage insects are primary pests, which can initiate major damage to the grains, and most of the storage insect pests are also able to commence their attack in the field before harvest (FAO, 1995). It is important to consider the traditional pest control methods used by farmers and integrate them with synthetic pesticides to increase affordability and enhance efficacy. The pest control methods will have to be developed taking into consideration the storage facilities that the farmers have at farm level.

\subsection{Potential Policy Issues for Consideration}

Most seedhouses in Zimbabwe do not bother to sell anything other than maize seed. The companies simply assume the seed of secondary crops would be derived from village markets (Rohrbach \& Mazvimavi, 2006). Community seed enterprises run by farmers along business lines is one way to increase the supply of unavailable self-pollinating crops to smallholder farmers. Furthermore, the involvement of all potential stakeholders will increase seed availability as what happened with soyabeans in Zimbabwe (Giller, 2008).

The market prices of commodities produced by farmers affect viability of the smallholder farming sector. If the prices are too low, farmers reduce or, in some cases, cease production. Farmers deserve better returns on their investments in seed to encourage them to continue investing (Langyintuo et al., 2010). The pricing model for commodities should be fairly balanced to keep farmers interested in producing a crop. The proper market price of commodities will keep the demand for seed high and in turn can increase the quality of seed as investment increases. A good example is the maize commodity price effect in Zimbabwe, where the guaranteed price increased production by smallholder farmers until problems were encountered in farmers not receiving payments from the Grain Marketing Board (GMB), the centralised state storage authority, mandated to purchase, store and re-sell grain from farmers. It was not until the 1980's when the government ensured access to credit for inputs, higher guaranteed maize prices, and marketing subsidies that the maize green revolution was fully embraced by smallholder farmers (Eicher \& Kupfuma, 1997 ). The change in the maize price made by the Government of Zimbabwe, to levels which GMB could not sustain, resulted in farmers reducing or quitting commercial maize production to focus on other viable crops.

The involvement of smallholder farmers in seed production has the potential of increasing access to seed by the 
local farmers compared to when they are consumers only. The involvement enables smallholder farmers to increase income as seed has more value compared to commodity crops. The policy on seed production may consider having a certain quota of all seed produced in the country for all crops, where possible, produced by the smallholder farmers.

A policy increasing the access to improved varieties by smallholder farmers will increase their potential production. A deliberate plan linking research institutions with smallholder farmer institutions will increase access to new germplasm. Permanent mechanisms for the cascading of improved varieties from national research and international research should be put in place as opposed to rely on NGOs whose mandate expires or changes quite often.

\section{Conclusions and Recommendations}

\subsection{Conclusion}

Farmers in Zaka district want seed of certain crops but are not able to access them as certified seed and these include crops such as sugar beans, groundnuts, cowpeas and sorghum. This affects food and nutrition security in the area. The lack of foundation seed for the seed crops in short supply and lack of technical knowledge on seed production are the main challenges farmers face in Zaka district. Certified maize seed is widely available for farmers to purchase. Pests and storage problems affect the majority of farmers in the smallholder sector and this is further compounded by poor storage facilities available to farmers. Such storage places as the bedroom and kitchen reduce the ability of farmers to effectively control pests. Lastly, the food security of smallholder farmers is partly affected by the lack of certified seed for crops which the farmers wish to grow.

\subsection{Recommendations}

A number of recommendations can be generated from the current study:

1) Training farmers on seed production and availing foundation seed have a potential to increase the capacity of farmers to improve yields of other crops other than maize. These two factors were considered to be the main limiting factors. The extension staff can be trained as trainers so that they can cascade the training to seed farmers. This model will reduce costs while increasing coverage as there are numerous grassroots extension officers in the country. The knowledge of farmers on sources of seed varieties and methods of seed production can be increased through field days (Note 2), exchange visits and study tours designed carefully to increase the learning experience of farmers. The Government of Zimbabwe and development agencies need to collaborate to increase resources available for the activities.

2) Farmers accessed certified seed, mostly for maize, and most other crop seeds are not readily available on the local market. For private companies, the study can be conducted further to see if the unavailable seed can be viably supplied commercially. Crops for which actual demand is available can be produced and be distributed through rural retailers in the area.

3) The government structures involved in formulating policies have to develop strategies that deliberately increase the availability of other seed crops to smallholder farmers to increase food security through linkages with research organisations. The availing of foundation seed of improved varieties will increase production of those varieties that farmers need.

4) Postharvest handling focusing on pest management in seed systems is integral for the success of any seed intervention as pest damage is very prevalent. Seed storage should focus on appropriate facilities as farmers were using chemicals but these were limited by the type of structures or storage places. Research should be commissioned to assess various seed storage structures which farmers can use.

5) The larger grain borer (LGB) issue requires further independent expert assessment to clarify the situation. If present, implications on maize seed storage can be far reaching.

6) A typical seed value chain analysis in the smallholder farming sector is required to fully engage all the actors and create an appropriate platform for effective feedback, co-learning, change in practices and ultimately use of good agriculture practices.

\section{Acknowledgements}

We are grateful to the Swiss Development Cooperation who through GRM International and the Seeds and Markets Project (SAMP), funded the study. We are thankful to Department of Agricultural Technical and Extension Services (Agritex) Zaka district officials for providing enumerators to conduct the survey. The enumerators and the farmers were very cooperative in the study and profound gratitude go to all of them. The SAMP project is gratefully acknowledged for allowing the study to be conducted within the framework of the 
project.

\section{References}

Anonymous. (2014). Climate Zaka -Masvingo World Climate Data. Retrieved July 20, 2014, from http://www.climatedata.eu/climate.php

Bellon, M. R., Adato, M., Becerril, J., \& Mindek, D. (2003). The Impact of Improved maize Germplasm on Poverty Alleviation: The case of Tuxpeṇo-Derived Material in Mexico. Discussion Paper No 162.International Food Policy Research Institute.2033 K Street N.W. Washington.

CIAT, CRS, World Vision, Care, AGRITEX, \& CIMMYT. (2009). Seed System Security Assessment, Zimbabwe. A study funded by the United States Agency for International Development. Office of Foreign Disaster Assistance. In July 2009 Rome: International Centre for Tropical Agriculture.

Daniel, I. O., \& Adetumbi, J. A. (2004). Seed supply for vegetable production at smallholder farms in south western Nigeria. Euphytica, 140, 189-196. http://dx.doi.org/10.1007/s10681-004-3035-0

David, S., \& Sperling, L. (1999). Improving technology delivery mechanisms: Lessons frombean seed systems research in Eastern and Central Africa. Agriculture and Human Values, 6, 381-388. http://dx.doi.org/10.1023/A:1007603902380

Dawes, M., Murota, R., Jera, R., Masara, C., \& Sola, P. (2009). Inventory of Smallholder Contract Farming Practices in Zimbabwe. A research report for SNV. SNV, Harare.

Department of the Surveyor General. (1984). Map of Zimbabwe (1: 1000 000): Natural farming regions and farming areas. Government Printers, Harare.

Eicher, C. K., \& Kupfuma, B. (1997). Zimbabwe's emerging maize revolution. In D. Byerlee, \& C. K. Eicher (Eds.), Africa's Emerging Maize Revolution. Lynne Reinner Publishers, Boulder, Colorado, USA.

FAO. (1995). The grain storage techniques - Evolution and trends in developing countries. FAO, Rome. Retrieved June 15, 2012, from http://www.fao.org/dorcep/T1838E/T1838E1f.htm

FAO. (2012). E-vouchers in Zimbabwe, Guidelines for agricultural input distribution. Emergency Rehabilitation and Coordination Unit, Harare, Zimbabwe. Food and Agriculture Organization of the United Nations.

FAO. (2014). Fertiliser use by crop in Zimbabwe. Retrieved January 2, 2015, from http://www.fao.org/docrep/009/a0395e/a0395e06.htm

Giller, K. (2008).The successful intensification of smallholder farming in Zimbabwe. LEISA magazine, 24, 2.

Giller, K. E., Murwira, M. S., Dhliwayo, D. K. C., Mafongoya, P. L., \& Mpepereki, S. (2011). Soyabeans and sustainable agriculture in southern Africa. International Journal of Agricultural Sustainability, 9(1), 50-58. http://dx.doi.org/10.3763/ijas.2010.0548

Herbert, Jnr, D. A. (2012). Stored grain Insect Pest Management. Tidewater Agricultural Research and Extension Centre (AREC). Virginia Tech University, Virginia. U.S.A

Jones, R. B., Audi, P. A., \& Tripp, R. (2001). The role of informal seed systems in disseminating modern varieties: example of pigeon pea in semi-arid area of Kenya. Experimental Agriculture, 37, 539-548. http://dx.doi.org/10.1017/S0014479701000461

Langyintuo, A. S., \& Setimela, P. (2009).Assessing the effectiveness of a technical assistance program: The case of maize seed relief to vulnerable households in Zimbabwe. Food Policy, 34, 377-387. http://dx.doi.org/10.1016/j.foodpol.2008.11.003

Langyintuo, A. S., Mwangi, W., Diallo, A. O., MacRobert, J., Dixon, J., \& Banziger, M. (2010). Challenges of the seed maize industry in eastern and southern Africa: A compeling case for public-private sector intervention to promote growth. Food Policy, 35, 323-331. http://dx.doi.org/10.1016/j.foodpol.2010.01.005

Monyo, E. S., \& Mgonja, M. A. (2004). A Community Based Seed Production System- Schools for Seed in Tanzania. Paper presented at the successful community based seed production strategies, co-organised by CIMMYT and ICRISAT, 3-6 August 2003, Harare, Zimbabwe.

Monyo, E. S., Mgonja, M. A., \& Rohrbach, D. (2004). Analysis of Seed Systems Development with Special Reference to Smallholder Farmers in Southern Africa: Issues and Challenges. A paper presented at the workshop on successful community based seed production strategies, co-organised by CIMMYT and ICRISAT, 3-6 August 2003. Harare, Zimbabwe. 
Mvumi, B. M., Tanyongana, R., \& Siziba, L. (2012). Baseline Survey Report for the Seeds And Markets Project (SAMP) in Zaka District, Zimbabwe. GRM International, Harare, Zimbabwe.

Nyagwaya, L. D. M., Mvumi, B. M., \& Saunyama, I. G. M. (2010). Occurrence and distribution of Prostephanus truncatus (Horn) (Coleoptera: Bostrichidae) in Zimbabwe. International Journal of Tropical Insect Science, 30, 4, 221-231. http://dx.doi.org/10.1017/S1742758410000342

Parwada, C., Gadzirayi, C., Karavina, C., Kibuku, F., Mandumbu, R., \& Madumbu, B. Z. (2012). TagetesMinuta Formulation Effect Sitophilus Zeamais (Weevils) Control in Stored Maize Grain. International Journal of Plant Research, 2(3), 65-68. http://dx.doi.org/10.5923/j.plant.20120203.04

Pelmer, D. P. (2005). Agriculture in the developing world: connecting innovation in plant breeding research to downstream applications. PNAS, 102(44), 15739-15746. http://dx.doi.org/10.1073/pnas.0505895102

Rohrbach, D., \& Mazvimavi, K. (2006). Do Seed Fairs Improve Food Security and Rural markets? Briefing Note No 3.ICRISAT. Bulawayo.

Rubyogo, J. C., \& Sperling, L. (2009). Developing Seeds Systems in Africa. In I. Scoones, \& J. Thompson (Eds.), Farmer First Revisited (pp. 384). Practical Action Publishing Ltd. Warwickshire, UK.

Rubyogo, J. C., Sperling, L., \& Assefa, T. (2007). A new Approach for facilitating farmers' access to bean seed. LEISA Magazine, 23(2), 27-29.

Rubyogo, J. C., Sperling, L., Nasirumbi, L., \& Kasambala, S. (2009). Developing seed systems with and for the marginalised: Case of common beans (Phaseolous vulgaris L.) in East, Central and Southern Africa. Devleoping Seed Systems in Africa. In I. Scoones, \& J. Thompson (Eds.), Farmer First Revisited (pp. 451). Practical Action Publishing Ltd. Warwickshire.

Setimela, P. S., Monyo, E., \& Banziger, M. (Eds.). (2004). Successful Community-based Seed Production Strategies. D.F. CIMMYT. Mexico.

Sperling, L., \& Cooper, H. D. (2003). Understanding seed systems in seed security. In: Improving the effectiveness and sustainability of seed relief. Proceedings of a stakeholders workshop in 26-28 May, 2003. Food and Agriculture Organization. Rome.

Svubure, O., Mupepereki, S., \& Makonese, F. (2010). Sustainability of maize-based cropping systems in rural areas of Zimbabwe:an assessment of the residual soil fertility effects of grain legumes on maize (Zea mays [L.]) under field conditions. International Journal of Engineering, Science and Technology, 2(7), 141-148.

TECA/FAO. (2012). Using Eucalyptus leaves to preserve maize and bean seed. Retrieved January 2, 2015, from http://teca.fao.org/discussion/using-eucalyptus-leaves-preserve-maize-and-bean-seed?page $=1$

Zerbe, N. (2001). Seed of hope, seeds of despair: Towards a political economy of the seed industry in southern African. Third World Quarterly, 22(4), 657-673. http://dx.doi.org/10.1080/01436590120071830

\section{Notes}

Note 1 . The e-voucher programme was a humanitarian response in which beneficiary smallholder farmers were issued with electronic cards (e-cards) similar to automated teller machine cards, allowing the farmers to purchase agricultural inputs ( including seed) of choice at designated retailers by swiping the cards. Development agencies deposited money into participating banks, which was withdrawn by farmers using the e-cards. The banks would pay the retailers based on the amounts of inputs purchased by the farmers.

Note 2. Field days are gatherings by farmers in Zimbabwe where neighbouring farmers, extension staffs and other stakeholders assemble at one farmer's homestead of field to witness good practices or successful implementation of new techniques of technologies by the host farmer. The field days are tool used by extension to increase knowledge-sharing among farmers.

\section{Copyrights}

Copyright for this article is retained by the author(s), with first publication rights granted to the journal.

This is an open-access article distributed under the terms and conditions of the Creative Commons Attribution license (http://creativecommons.org/licenses/by/3.0/). 